\title{
The Period of Ovulation and Presence of the First Polar Body of Ova Ovulated in the House Musk Shrew (Suncus murinus)
}

\author{
Tetsuya MATSUZAKI'1), Kanae MATSUZAKI'1), \\ Minesuke YOKOYAMA ${ }^{2)}$, and Muneo SAITO ${ }^{3)}$
}

\begin{abstract}
1)Division of Laboratory Animal Resources, National Institute of Neuroscience, National Center of Neurology and Psychiatry, 4-1-1 Ogawa-Higashi-cho, Kodaira-shi, Tokyo 187, 2)Section of Reproductive Engineering, Mitsubishi Kasei Institute of Life Sciences, 11 Minamioya, Machida-shi, Tokyo 194, and

${ }^{3)}$ Central Institute for Experimental Animals, 1430 Nogawa, Miyamae-ku, Kawasaki-shi 216, Japan
\end{abstract}

\begin{abstract}
The period of ovulation in mature house musk shrews was examined in a natural mating group and a superovulation group treated with gonadotropin. In the natural mating group, ovulation started $14 \mathrm{hr}$ after mating in 3 of the 7 house musk shrews (42.8\%), and occurred in all 5 house musk shrews by $15 \mathrm{hr}$ after mating. In the superovulation group, ovulation started $13 \mathrm{hr}$ after the administration of hCG in 3 of the 5 house musk shrews, and was observed in all 5 shrews by $16 \mathrm{hr}$ after the administration. In the natural mating group, ovulated ova were collected from the ovarian bursa of 14 house musk shrews 14-20 hr after mating (mean, $2.2 \pm 1.0$ ova) and from the oviduct of 42 animals 14-24 hr after mating (mean, $3.6 \pm 1.8$ ova). Among the ova ovulated 14-16 hr after mating, both mature ova with the first polar body and immature ova without the first polar body were observed. In the superovulation group, ovulated ova were collected from the ovarian bursa of 31 house musk shrews 13-22 hr after the administration of hCG (mean, $9.7 \pm 6.8$ ova), and from the oviduct of 28 animals 13-24 hr after the administration of hCG (mean, $20.0 \pm 11.7$ ova). There were also mature and immature ova in the ova ovulated 13-16 $\mathrm{hr}$ after the administration of $h C G$. The time when ova ceased to be recovered from the ovarian bursa roughly coincided with the time when new corpora lutea ceased to be found in the ovaries. These findings suggested that the period of ovulation of house musk shrews was 14-20 hr after mating in the natural mating group and 13-22 hr after the administration of hCG in the superovulation group. Both the natural mating group and superovulation group ovulated both mature ova with the first polar body and immature ova without the first polar body.
\end{abstract}

Key words: first polar body, natural mating, ovarian bursa, ovulation, superovulation

(Received 13 January 1997 / Accepted 31 May, 1997)

Address corresponding: T. Matsuzaki, Division of Laboratory Animal Resources, National Institute of Neuroscience, National Center of Neurology and Psychiatry, 4-1-1 Ogawa-Higashi-cho, Kodaira-shi, Tokyo 187, Japan. 


\section{Introduction}

There are two kinds of temporal regulation of ovulation in mammals, one occurring periodically as in mice $[22,29]$ and other animal species $[17,23,24,27,28]$ and the other which is induced by mating as seen in rabbits $[1,2]$. In the latter kind of animals, the ovarian follicles show repeated cycles of growth, closure, and regression during the breeding season, and ovulation is induced by mating or other similar stimuli. There are two types of expression of estrus in this group of animals. One is the rabbit-type in which there is always a small number of mature ovarian follicles in the ovary during the reproductive period, and the other is the cattype in which growth and regression of the ovarian follicles periodically repeats and estrus occurs coincidentally with this cycle [26]. The house musk shrew (Suncus murinus) shows the former type of estrus, and mating is therefore always possible in the species $[3,4$, $8,11,20]$.

In the house musk shrew, the roles of ovarian estrogen in the growth and maintenance of the accessory genital organs differ from those in other mammals. The removal of the ovary does not significantly affect the tissue structures of the uterus and vagina, and the weights of the uterus and vagina are independent of ovarian hormones $[6,25]$. Ovulation can be induced by the administration of a single gonadotropin (PMSG, hCG, FSH or LH) in the house musk shrew [5]. In the mouse [7, 33], hamster [10], and rabbit [16], superovulation can be induced, and we have developed a superovulation induction method for the house musk shrew by a combined administration of PMSG and hCG (manuscript submitted).

In the present study, we examined the time of ovulation in house musk shrews after natural mating and after inducing superovulation by the administration of hCG.

\section{Materials and Methods}

Three to four-month-old male and female house musk shrews (Jic: SUN Strain) $[18,19]$ bred in the Central Institute for Experimental Animals were used. The house musk shrews were kept in a room at $22 \pm 2^{\circ} \mathrm{C}$, with humidity at $55.5 \pm 5 \%$ and ventilation $10-15$ times/ $\mathrm{hr}$ with fresh air. The lighting condition was a 12-hr light period (8.00 a.m. -8.00 p.m.) and a 12-hr dark period. The animals were fed solid feed (CIEA-305) [32] and allowed to drink tap water ad libitum.

In the natural mating group, each female house musk shrew was mated with a male, and after the mating was confirmed (the male licks his penis after showing mounting behavior), the female and male of each pair were separated after being housed a cage for $2 \mathrm{hr}$. In the superovulation group, the females were then superovulated by receiving an intraperitoneal injection of 5.0 iu pregnant mare's serum gonadotropin (PMSG) followed by an intraperitoneal injection of $5.0 \mathrm{iu} \mathrm{hu-}$ man chorionic gonadotropin (hCG) $72 \mathrm{hr}$ later.

The PMSG (5.0 iu) and hCG (5.0 iu) were each dissolved in $0.2 \mathrm{ml}$ physiological saline before injection. Ova were collected $12,13,14,15,16,17,18,20,22$ and $24 \mathrm{hr}$ after the first mating in the natural mating group and at the same time points after the administration of hCG in the superovulation group. To collect the ova, the female house musk shrews were killed by cervical dislocation under anesthesia with ether, the ovaries and uterus were dissected out and placed on a filter paper, and the fat was removed from the uterus and ovaries. The ovaries and oviduct were then transferred to a dish with a culture medium (TYH), and the ova were collected from the ovarian bursa and oviduct under a dissecting microscope. In some of the ova collected with the cumulus cells, the cumulus cells were removed by repeated pipetting with a glass capillary, and live ova were observed under an inverted microscope. Ovulation was confirmed by the presence of the corpora lutea on the ovary surface.

\section{Results}

\section{Period of ovulation in the natural mating group}

Table 1 shows the period of ovulation in the natural mating group. Large ovarian follicles were observed in the ovary of the female house musk shrew $13 \mathrm{hr}$ after mating, and $14 \mathrm{hr}$ after mating, ova were collected from 3 of the 7 shrews mated. Of these 3 shrews, 2 had large ovarian follicles and corpora lutea in the ovary, and one had fungiform corpora lutea but no ovarian follicles in the ovary. In each ovary of the other 4 animals without ovulation, several large ovarian follicles were observed. Fifteen hr after mating, ovulation was observed in all five of the house musk shrews 
Table 1. The ovulation period of the house musk shrews after copulation

\begin{tabular}{|c|c|c|c|c|c|c|c|c|c|}
\hline \multirow{2}{*}{$\begin{array}{l}\text { Time (hr) } \\
\text { after } \\
\text { copulation }\end{array}$} & \multirow{2}{*}{$\begin{array}{c}\text { No. of } \\
\text { animals } \\
\text { examined }\end{array}$} & \multirow{2}{*}{$\begin{array}{c}\text { No. of (\%) } \\
\text { animals } \\
\text { ovulated }\end{array}$} & \multicolumn{7}{|c|}{ No. of $(\%)$ ovum recovered and situation of recovery } \\
\hline & & & Total (Means \pm SD) & $\begin{array}{c}\text { With } \\
\text { cumulus } \\
\text { cells }\end{array}$ & $\begin{array}{l}\text { Without } \\
\text { cumulus } \\
\text { cells }\end{array}$ & $\begin{array}{l}\text { No. of } \\
\text { animals }\end{array}$ & $\begin{array}{c}\text { Ovarian } \\
\text { bursa }\end{array}$ & $\begin{array}{c}\text { No. of } \\
\text { animals }\end{array}$ & Oviduct \\
\hline 12 & 3 & 0 & 0 & & & & & & \\
\hline 13 & 6 & 0 & 0 & & & & & & \\
\hline 14 & 7 & $3(42.8)$ & $9(3.0 \pm 2.7)$ & $8(88.9)$ & $1(11.1)$ & $3 / 3$ & $6(66.7)$ & $2 / 3$ & $3(33.3)$ \\
\hline 15 & 5 & $5(100)$ & $22(4.4 \pm 1.2)$ & $20(90.9)$ & $2(9.1)$ & $5 / 5$ & $13(59.1)$ & $4 / 5$ & $9(40.9)$ \\
\hline 16 & 8 & $8(100)$ & $34(4.3 \pm 1.3)$ & $33(97.1)$ & $1(2.9)$ & $3 / 8$ & $7(20.6)$ & $8 / 8$ & $27(79.4)$ \\
\hline 17 & 6 & $6(100)$ & $28(4.7 \pm 2.6)$ & $28(100)$ & 0 & $1 / 6$ & $2(7.1)$ & $6 / 6$ & $26(92.9)$ \\
\hline 18 & 5 & $5(100)$ & $14(2.8 \pm 0.8)$ & $14(100)$ & 0 & $1 / 5$ & $1(7.1)$ & $5 / 5$ & $13(92.9)$ \\
\hline 20 & 5 & $5(100)$ & $21(4.2 \pm 1.1)$ & $20(95.2)$ & $1(4.8)$ & $1 / 5$ & $2(9.5)$ & $5 / 5$ & $19(95.2)$ \\
\hline 22 & 6 & $6(100)$ & $24(4.0 \pm 0.9)$ & $12(50.0)$ & $12(50.0)$ & $0 / 6$ & 0 & $6 / 6$ & $24(100)$ \\
\hline 24 & 6 & $6(100)$ & $29(4.8 \pm 1.5)$ & $23(79.3)$ & $6(20.7)$ & $0 / 6$ & 0 & $6 / 6$ & $29(100)$ \\
\hline
\end{tabular}

examined (mean, 4.4 ova).

Ovulated ova were collected from the ovarian bursa of 14 animals $14-20 \mathrm{hr}$ after mating. In particular, the beginning of ovulation at $14 \mathrm{hr}$ after mating produced a high collection rate $(66.7 \%)$. From the oviduct, ovulated ova were collected from the upper oviduct 14-16 hr after mating, and 17-24 hr after mating ovulated ova were collected from the ampulla of the oviduct and the lower oviduct. No new corpus luteum was found in the ovary $22 \mathrm{hr}$ after mating.

The ova collected with the cumulus cells were covered by the thick cumulus cells, and some of the cells were removed by repeated pipetting with a glass capillary. Of the 7 viable ova from 2 house musk shrews sacrificed at $15 \mathrm{hr}$ after mating, 4 had the first polar body but 3 were immature ova without the first polar body. Similarly, of the 8 ova from 2 of the house musk shrews examined $16 \mathrm{hr}$ after mating, 2 mature ova had the first polar body while 6 were immature ova without the first polar body. Of the ova of animals collected 18 hr after mating, the ova of one animal were all mature ova with the first polar body, while the ova of another animal were all immature ova without the first polar body. Sperm were observed in the perivitelline cavity of one mature ovum. The ova of a house musk shrew collected $21 \mathrm{hr}$ after mating were both with and without the first polar body. Penetration of sperm was observed in the pellucid zone of all of these ova (Table 3 ).

\section{Period of ovulation in the superovulation group}

Table 2 shows the period of ovulation in the group in which superovulation was induced by the administration of PMSG and hCG. Ovulation was not observed at $12 \mathrm{hr}$ after the administration of hCG (0/4 animals), but in the ovary of these 4 animals, large ovarian follicles were observed forming a continuous array. Thirteen hr after the administration of hCG, ovulation was observed in 3 of the 5 animals examined, and large ovarian follicles were observed in the ovary of the 2 shrews without ovulation. Sixteen hr after the administration of hCG, ova were collected from all five animals examined, but large ovarian follicles were also observed in the ovary.

One to twenty-six (mean, $9.7 \pm 6.8$ ) ovulated ova were collected from the ovarian bursa in 31 of the 34 house musk shrews observed 13-22 hr after the administration of hCG. During the early ovulation period, almost all ova were collected from the ovarian bursa, and the ovarian bursa remained a site of ovum collection, though at a low rate, at $22 \mathrm{hr}$ after the administration of hCG. The number of ova collected from the ovarian bursa per house musk shrew was the largest at $16 \mathrm{hr}$ after the administration of hCG (12-26 ova). From $17 \mathrm{hr}$ after the hCG administration, the number of the ova collected from the ampulla of the oviduct and the lower part of the oviduct increased with time. There were no new corpus lutea in the ovaries at $24 \mathrm{hr}$ after the administration of hCG.

In some of the ova collected with the cumulus cells, the cumulus cells were removed, and the ova inside were observed. Fourteen hr after the administration of hCG, the first polar body was observed in 7 of the 15 
Table 2. The ovulation period of the house musk shrews in which superovulation was induced with injections of PMSG and hCG

\begin{tabular}{|c|c|c|c|c|c|c|c|c|c|}
\hline \multirow{2}{*}{$\begin{array}{l}\text { Time }(\mathrm{hr}) \\
\text { after } \mathrm{hCG} \\
\text { injection }\end{array}$} & \multirow{2}{*}{$\begin{array}{l}\text { No. of } \\
\text { animals } \\
\text { examined }\end{array}$} & \multirow{2}{*}{$\begin{array}{c}\text { No. of }(\%) \\
\text { animals } \\
\text { ovulated }\end{array}$} & \multicolumn{7}{|c|}{ No. of $(\%)$ ovum recovered and situation of recovery } \\
\hline & & & Total (Means \pm SD) & $\begin{array}{l}\text { With } \\
\text { cumulus } \\
\text { cells }\end{array}$ & $\begin{array}{c}\text { Without } \\
\text { cumulus } \\
\text { cells }\end{array}$ & $\begin{array}{c}\text { No. of } \\
\text { animals }\end{array}$ & $\begin{array}{c}\text { Ovarian } \\
\text { bursa }\end{array}$ & $\begin{array}{c}\text { No. of } \\
\text { animals }\end{array}$ & Oviduct \\
\hline 12 & 4 & 0 & 0 & & & & & & \\
\hline 13 & 5 & $3(60.0)$ & $31(10.3 \pm 8.0)^{\mathrm{a}}$ & $30(96.8)$ & $1(3.2)$ & $3 / 3$ & $30(96.8)$ & $1 / 3$ & $1(3.2)$ \\
\hline 14 & 5 & $4(80.0)$ & $27(6.8 \pm 5.9)^{\mathrm{a}}$ & $27(100)$ & 0 & $4 / 4$ & $27(100)$ & $0 / 4$ & 0 \\
\hline 15 & 5 & $4(80.0)$ & $38(9.5 \pm 6.2)^{\mathrm{a}}$ & $37(97.4)$ & $1(2.6)$ & $4 / 4$ & $29(76.3)$ & $2 / 4$ & $9(23.7)$ \\
\hline 16 & 5 & $5(100)$ & $129(25.8 \pm 8.4)^{b}$ & $124(96.1)$ & $5(3.9)$ & $5 / 5$ & $89(69.0)$ & $4 / 5$ & $40(31.0)$ \\
\hline 17 & 5 & $5(100)$ & $146(29.2 \pm 10.8)^{b}$ & $136(93.2)$ & $10(6.8)$ & $5 / 5$ & $51(34.9)$ & $5 / 5$ & $95(65.1)$ \\
\hline 18 & 5 & $5(100)$ & $156(31.2 \pm 4.6)^{b}$ & $152(97.4)$ & $4(2.6)$ & $2 / 5$ & $29(18.6)$ & $5 / 5$ & $127(81.4)$ \\
\hline 20 & 5 & $5(100)$ & $174(34.8 \pm 18.3)^{b}$ & $169(97.1)$ & $5(2.9)$ & $5 / 5$ & $37(21.3)$ & $5 / 5$ & $137(78.7)$ \\
\hline 22 & 3 & $3(100)$ & $76(25.3 \pm 7.8)^{\mathrm{b}}$ & $71(93.4)$ & $5(6.6)$ & $3 / 3$ & $8(10.5)$ & $3 / 3$ & $68(89.5)$ \\
\hline 24 & 3 & $3(100)$ & $83(27.7 \pm 7.2)^{b}$ & $80(96.4)$ & $3(3.6)$ & $0 / 3$ & 0 & $3 / 3$ & $83(100)$ \\
\hline
\end{tabular}

Values with different alphabetical superscripts within each column are significantly different from each other $(\mathrm{p}<0.01)$ The values at $18 \mathrm{hr}, 20 \mathrm{hr}$ and $22 \mathrm{hr}, 24 \mathrm{hr}$ are not significantly different from each other, Student's $t$-test.

Table 3. Presence of the first polar body of ovulated ova in the house musk shrews

\begin{tabular}{|c|c|c|c|c|c|}
\hline \multirow{2}{*}{ Ovulation } & \multirow{2}{*}{$\begin{array}{l}\text { Time (hr) after } \\
\text { copulation or } \\
\text { hCG injection }\end{array}$} & \multirow{2}{*}{$\begin{array}{c}\text { No. of } \\
\text { animals } \\
\text { examined }\end{array}$} & \multirow{2}{*}{$\begin{array}{c}\text { No. of ova } \\
\text { ovulated }\end{array}$} & \multicolumn{2}{|c|}{ Development of ovum } \\
\hline & & & & $\begin{array}{l}\text { With 1st } \\
\text { polar body }\end{array}$ & $\begin{array}{l}\text { Without lst } \\
\text { polar body }\end{array}$ \\
\hline \multirow{4}{*}{ Copulation } & 15 & 2 & 7 & 4 & 3 \\
\hline & 16 & 2 & 8 & $2^{1)}$ & 6 \\
\hline & 18 & 2 & 7 & $4^{2)}$ & 3 \\
\hline & 21 & 1 & 4 & $2^{3\}}$ & 2 \\
\hline \multirow{3}{*}{$\begin{array}{l}\text { Super- } \\
\text { ovulation }\end{array}$} & 14 & 1 & 15 & 7 & 8 \\
\hline & 17 & 1 & $19(8)^{4)}$ & 2 & 6 \\
\hline & 18 & 1 & $23(10)$ & 3 & 7 \\
\hline
\end{tabular}

1) Sperm adhered to cumulus cells of 1 ovum. 2) Sperm were confirmed in the perivitelline space of 1 ovum. 3) Sperm penetrated all of the ova. 4) Parentheses indicate numbers of ova examined.

ova, and the remaining 8 ova were immature ova without the first polar body (Table 3 ). Seventeen to eighteen hr after the administration of hCG, there were ova with and without the first polar body, showing the same result as in the natural mating group.

\section{Discussion}

To clarify the time of ovulation in the house musk shrew, ovulation after natural mating and after hormone treatments was examined. The ovaries of the house musk shrew are very small, measuring about $1.5 \mathrm{~mm}$, which is much smaller than the ovaries of the mouse, and the short oviduct goes around the ovary once and adheres to the ovarian bursa $[9,13]$.

The time of ovulation in the house musk shrew has been reported to be $13 \mathrm{hr}$ [21] or $15 \mathrm{hr}$ [12] after mating in ovulation induced by natural mating. In the present study, it was $14 \mathrm{hr}(3 / 7 ; 42.9 \%)$ after mating in the natural mating group and $13 \mathrm{hr}(3 / 5 ; 60.0 \%)$ after the administration of hCG in the superovulation group. In both groups, ova were collected from the ovarian bursa. It has been shown that ovulated ova induced by mating remain in the ovarian bursa for a very short time and reach the ampulla of the oviduct even in an animal in which ovulation is in progess [21], but Hasler 
[12] was able to collect ova from the ovarian bursa of two house musk shrews among 16 animals in which mating was confirmed. In our study, 1 to 4 ova per animal were collected from the ovarian bursae of 14 females after mating, and 1 to 26 ova per animal were collected from the ovarian bursae of 29 females in the superovulation group. These results indicate that ovulated ova do not move to the fimbria immediately but rather stay temporarily in the ovarian bursa.

The cessation of ovulation was estimated to be $20 \mathrm{hr}$ after mating in the natural mating group and $22 \mathrm{hr}$ after the administration of $\mathrm{hCG}$ in the superovulation group, since new corpora lutea were observed only during the period when ova could be collected from the ovarian bursa. The reason for the longer ovulation period in the superovulation group compared to the natural mating group was probably because the growth of many ovarian follicles and the maturation of the ova induced by the administration of PMSG were not simultaneous.

In most cases, ovulation in mammals occurs after the formation of the first polar body (metaphase 2) [14, 15]. In the house musk shrew, ovulation occurs either after the discharge of the first polar body following the resumption of cleavage of mature oocytes, which is 13 to $16 \mathrm{hr}$ after mating, or before the formation of the first polar body [12]. In the present study, more than half $(15 / 26)$ of the ova collected 13 to $14 \mathrm{hr}$ after mating were immature and thus lacking the first polar body (metaphase 1). This finding suggests that completion of the first meiosis and formation of the first polar body occur within the oviduct, as is the case with dogs.

Much remains to be clarified regarding the process of maturation of ovulated ova as well as fertilization in the house musk shrew. A detailed examination of the characteristics of ovulated ova induced by the administration of hormones is also necessary.

\section{Acknowledgment}

This study was supported by a Grant-in-Aid (Studies on Research Resource Banks) for Scientific Research from the Ministry of Health and Welfare, Japan.

\section{References}

1. Adams, C.E., Aitken, F.C., and Worden, A.N. 1966. The rabbit. pp. 396-448. In: The UFAW Handbook on the Care and Management of Laboratory Animals 3rd. (Lane petter, W., Worden, A.N., Berton Hill, F., Paterson, J.S., and Vevers, H.G. eds.), E. \& S. Livingstone LTD.

2. Chai, C.K. and Crary, D.D. 1971. Conjoined twinning in rabbits. Teratol. 4: 433-444.

3. Dryden, G.L. 1969. Reproduction in suncus murinus. J. Reprod. Fert (Suppl) 6: 377-396.

4. Dryden, G.L. 1975. Establishment and maintenance of shrew colonies. Internat. Zoo Year book 15: 12-18.

5. Dryden, G.L. and Pucek, Z. 1975. Insectivores in reproduction studies, with emphasis on ovulation in American Asian, and European shrews. pp. 39-50. In: The Laboratory Animal in the Study of Reproduction (Antikatzides, T.H., Erichsen, S., and Spiegel, A.eds.), Gustav. Fischer Verlag. Stuttgart. New York.

6. Dryden, G.L. and Anderson, J.N. 1977. Ovarian hormone: Lack of effect on reproductive structures of female Asian musk shrews. Science 197: 782-784.

7. Fowler, R.E. and Edwards, R.G. 1957. Induction of superovulation and pregnancy in mature mice by gonadotrophins. J. Endocrinol. 15: 374-384.

8. Furumura, K., Kuriki, T., and Miyazaki, S. 1984. Growth and sexual maturation of the male house musk shrew (Suncus murinus). Exp. Anim. 33: 193-200.

9. Furumura, K., Kuriki, Ota, K., and Yokoyama, A. 1985. Reproduction. pp. 126-139. In: Development of New Laboratory Animals. In suncus murinus, Biology of the laboratory shrew (Kondo, K., Oda, S., Kitoh, J., Ota, K., and Isomura, G. eds.), Press, Tokyo.

10. Greenwald, G.S. 1962. Analysis of superovulation in the adult hamster. Endocrinol. 71: 378-389.

11. Hasler, M.J., Hasler, J.F., and Nalbandov, A.V. 1977. Comparative breeding biology of musk shrew (Suncus murinus) from Guam and Madagasukal. J. Mammal. 58: 285-290.

12. Hasler, M.J. and Nalbandov, A.V. 1980. Ovulation, ovum maturation and changes in plasma and adrenal progesterone concentrations in the musk shrew (Suncus murinus). Biol. Reprod. 22: 377-381.

13. Inoue, M., Oda, S., Shimamura, K., and Kameyama, Y. 1985. Development and abnormal development. pp. 140 154. In: Development of New Laboratory Animals. In suncus murinus, Biology of the laboratory shrew (Kondo, K., Oda, S., Kitoh, J., Ota, K., and Isomura, G. eds.), Press, Tokyo.

14. Iritani, A. and Sato, H. 1982. Control mechanism of maturation in ovum and sperm. pp. 11-24. In: Mammalian Reproductive Physiology-Aspects of its Animal Experimentation (Suzuki, Y. ed.), Soft Science, Inc., Tokyo.

15. Iritani, A., Suzuki, S., and Inouye, M. 1981. Preimplantation. pp. 7-51. In: Early Reproduction of Mammalian (Seo, S., Kato, T., Iritani, A., Suzuki, S., and Date, R. eds.), Rikogakusya, Tokyo.

16. Ishijima, Y., Ito, M., and Chang, G.J. 1969. The effect of estrogen on the induced superovulation by PMS in rabbits 2. Jap. J. Animal Reprod. 15: 109-111.

17. Kita, M., Kobayashi, H., Ino, T., and Nakata, K. 1979. 
Vaginal smear cycle in 4-day cyclic Chinese hamsters, Cricetulus griseus. Exp. Anim. 28: 11-16.

18. Matsuzaki, T., Saito, M., and Yamanaka, M. 1984. Planned reproduction of the house musk shrew (Suncus murinus). Exp. Anim. 33: 223-226.

19. Matsuzaki, T., Tanaka, T., Saito, R., Yamanaka, M., Saito, M., and Nomura, T. 1992. Establishment of an outbred strain (Jic:SUN) in the house musk shrew, Suncus murinus. Exp. Anim. 41: 167-172.

20. Morita, S. 1968. Reproduction of the Riukiu musk shrew, Suncus murinus riukiuanus Kuroda, 1. On the breeding season size of litter, embryonic mortality, transference of ovum and duration of gestation. Sci. Bull. Fac. Lib. Arts. and Educ. Nagasaki Univ. 15: 17-40.

21. Morita, S. 1968. On the copulation and ovulation of the riukiu musk shrew, Suncus murinus riukiuanus Kuroda. Biolog. Lab., Faculty of Education, Nagasaki Univ. Nagasaki 19: 85-95.

22. Nobunaga, T., Nakamura, K., and Yoshida, Y. 1965. Influence of breeding and environment in estrous cycle (Vaginal smear) of mouse. J. Domest. Anim. Breed. 11: 715.

23. Ogawa, S. and Agematsu, Y. 1984. Reproductive physiological. pp. 110-128. In: Reproductive Physiological (Ishibasi, M., Takahashi, J., Sugawara, S., and Yasuda, Y. eds.), Kodansha, Tokyo.

24. Parks, A.S. 1931. The reproductive processes of certain mammals. Part 1. The oestrous cycle of the chinese hamster (Cricetulus griseus). Proc. Roy. Soc. Biol. 108: 138-147.

25. Sasamoto, S. 1982. Development of ovulation and maturation of follicle. pp. 201-211. In: Mammalian
Reproductive Physiology-Aspects of its Animal Experimentation (Suzuki, Y. ed.), Soft Science, Inc., Tokyo.

26. Scott, T.T. 1970. Cats. pp. 192-208. In: Reproduction and Breeding Techniques for Laboratory Animals (Hafez, E. S. E. ed.), Lea and Febiger, Philadelphia.

27. Sugawara, S. 1984. Reproductive physiological. pp. 104 110. In: Laboratory Animal Science; Rat (Ishibasi, M., Takahashi, J., Sugawara, S., and Yasuda, Y. eds.), Koudanshiya, Tokyo.

28. Sugawara, S., Umezu, M., Hasegawa, Y., Sensui, N., and Mizuno, H. 1984. Reproductive physiological. pp. 128 162. In: Laboratory Animal Science Rat (Ishibasi, M., Takahashi, J., Sugawara, S., and Yasuda, Y. eds.), Koudanshiya, Tokyo.

29. Toyoda, U., Iritani, A., Oshima, K., and Suzuki, S. 1981. Estrous cycle and ovulation. pp. 123-167. In: Early Reproduction of Mammalian (Seo, S., Kato,T., Iritani, A., Suzuki, S., and Date, R. eds.), Rikogakusya, Tokyo.

30. Tsutsui, T. 1975. Studies on the reproduction in the dog. $\mathrm{V}$. On cleavage and transport of fertilized ova in the oviduct. Jap. J. Anim. Reprod. 21: 70-75.

31. Tsutsui, T. and Shimizu, T. 1975. Studies on the reproduction in the dog. 4 . On the fertile period of ovum after ovulation. Jap. J. Anim. Reprod. 21: 70-75.

32. Yamanaka, M., Matsuzaki, T., and Saito, M. 1983. Length and weight of gastrointestinal tracts of pikas, suncus, millardias, mice and rats. Exp. Anim. 32: 47-49.

33. Yokoyama, M. and Hioki, K. 1990. The copulation rate and the embryo recovery rate following induced superovulation in various strains of mice. J. Mamm. Ova. Res. 7: 89-94. 